\title{
Brasil e Portugal: a literatura em tempos de ditadura
}

\author{
Ernani Hermes ${ }^{1}$
}

O livro Brasil e Portugal: a ditadura entre luzes e sombras - leituras literárias, que compreende uma antologia de textos organizada por Inara de Oliveira Rodrigues e Silvia Niederauer, foi editado pela Universidade Regional Integrada do Alto Uruguai e das Missões e publicado no final do ano de 2015. O volume traz uma série de ensaios que propõe a leitura de textos literários e de outras produções culturais, como o cinema e a música, voltados à relação com os períodos de exceção vividos pelos dois países.

Inicialmente, Regina Zilberman, em texto introdutório, desenvolve reflexões sobre os regimes totalitários do século XX, contextualizando as ditaduras no Brasil e em Portugal. Sequencialmente, Maria da Glória Bordini, em seu depoimento, relata como era o cotidiano no regime militar, enfatizando o universo acadêmico ao rememorar uma época em que o medo, a (auto)censura e o silenciamentos se faziam presentes no dia a dia dos brasileiros.

No artigo seguinte, Lizandro Carlos Calegari analisa a questão do trauma na produção cultural brasileira no período pós-ditatorial, focalizando a produção literária e cinematográfica. Já o texto de José Luiz Fornos, intitulado "Portugal e o Salazarismo" situa o leitor no contexto cultural, político e social do regime de Salazar.

Miriam Denise Kelm traz reflexões sobre a ditadura militar brasileira pela via da dramaturgia. Por seu turno, Jane Tutikian apresenta algumas considerações sobre o exercício do poder salazarista na África lusófona, a partir da obra da ficcionista portuguesa Lídia Jorge.
O texto de Agnaldo Rodrigues da Silva retoma questionamentos sobre as relações entre teatro e política no contexto da ditadura militar brasileira a partir de A gota d'água, de Chico Buarque e Paulo Pontes (1998) e Os degraus, de Augusto Sobral (1964). A seguir, Inara de Oliveira Rodrigues dedica-se às questões relacionadas à literatura como compromisso estético e político ao analisar crônicas de José Saramago.

André Mitidieri e Mirta Cristina Parcianello de Freitas discutem, consecutivamente, a obra $O 35^{\circ}$ aniversário de Inês, de Tânia Jamardo Faillace (1971), indicando o retorno ao passado em meio às privações da liberdade. Já Paulo Roberto Alves dos Santos, se debruça sobre a dimensão literária da música popular brasileira no contexto da ditadura militar.

Luciana Éboli, por sua vez, dedica-se à análise do texto teatral "Se correr o bicho pega, se ficar o bicho come”, de Uduvaldo Vianna Filho e Ferreira Goullar (1966) focalizando as questões político-ideológicas problematizadas na obra. Segue-se o texto de Silvia Niederauer, "A morte em vida do povo brasileiro: Incidente em Antares", no qual ela estuda a figuração da ditadura militar no romance Incidente em Antares, de Érico Verissimo (1976) a partir da alegoria.

No texto seguinte, Miguel Rettenmaier, aproxima a literatura do jornalismo e propõe novos olhares a textos recuperados de Josué Guimarães, enquanto Ana Paula Porto e Luana Porto analisam também narrativas brasileiras contemporâneas, mas atentando para as relações entre memória e violência. Posteriormente, Denise Almeida Silva dedica-se à análise das narrativas testemunhais da antolo-

1 Acadêmico de Letras-Inglês na Universidade Regional Integrada do Alto Uruguai e das Missões (URI), vinculado ao grupo de pesquisa "Literatura e História: diálogos interdisciplinares". Universidade Regional Integrada do Alto Uruguai e das Missões (URI). ORCID: http:// orcid.org/o000-0002-0029-2627. E-mail: ernani.hermes@gmail.com 
gia Caminhando e contando, organizada por Marcia Paraquett e Sávio Siqueira (2015), assim, igualmente contribuindo para os estudos sobre a construção da memória da ditadura por intermédio da literatura.

No penúltimo texto do livro, Vera Prola Farias analisa o romance Quarup, de Antônio Callado (1984), focalizando temas como identidade, política e utopia, enquanto, no último artigo da antologia, Maria Thereza Veloso dedica-se aos poemas de Sidônio Muralha, reunidos no volume Poemas de Abril (1974), pela perspectiva da Análise do Discurso.

Essa antologia traz à tona uma questão que é, inegavelmente, cara à Teoria Literária: os entrecruzamentos entre a ficção e a história. Assim, considera-se que essas duas formas de narração se entrecruzam em vários caminhos, seja na ficcionalização de fatos/personagens históricos, seja na refiguração do passado via arte literária, como indica Paul Ricoeur (1997) na sua célebre trilogia Tempo e Narrativa. Dessa forma, a literatura toma para si os acontecimentos da história a fim de, a partir da articulação estética da linguagem, propor olhares diversificados sobre eles. Já que a historiografia oficial é a escrita da história dos vencedores, a escrita literária permite romper com o silenciamento de vozes que foram apagadas por meio da violência e do autoritarismo.

Por esse ângulo, tomamos de Walter Benjamin a metáfora de "escovar a história a contrapelo" (2012, p. 245). Por seu intermédio, entende-se que, ao escrever a história, deve-se pensar na preservação da memória das vítimas dos períodos de exceção, como as dos regimes fascista e nazista, que emergem no contexto em que Benjamin desenvolve sua teoria, mas também se torna possível expandir o seu sentido para as ditaduras ibéricas e latino-americanas. Em outros termos, o "contrapelo" compreende a narração da História não na perspectiva dos vencedores, mas sim dos vencidos, dos mortos e dos sobreviventes, que foram vítimas da violência: somente então "[...] a humanidade redimida obterá o seu passado completo. Isso quer dizer: somente para a humanidade redimida o seu passado tornou-se citável, em cada um de seus momentos" (BENJAMIN, 2012, p. 242).
Desse modo, ainda segundo esse filósofo, "o passado traz consigo um índice secreto, que o impele à redenção" (2012, p. 242). Assim, para que possamos nos apropriar do passado, e por extensão, alcançarmos a redenção, necessitamos, antes de tudo, entender esse passado, o que só é possível se formos além da história oficial, ou seja, precisamos recorrer à "história dos vencidos", justamente para que as vítimas não sejam apagas dos rastros da história.

Nesse sentido, se faz pertinente o estudo da Literatura Portuguesa e da Literatura Brasileira quando estabelecem um íntimo diálogo com a história de seus países. Para o caso que aqui interessa, trata-se da importância de constante (re)visão dos regimes ditatoriais do século XX que marcaram essas nações, como o regime de ditadura militar no Brasil e o salazarismo em Portugal. Esses momentos históricos são revisitados/(re)visados pela ficção literária, seja a produzida naquele tempo, em constante luta com os respectivos órgãos de censura, seja a literatura atual, que se volta ao passado para refigurá-lo na contemporaneidade.

Desse modo, pode-se perceber assim, nessa significativa reunião de textos, o anseio da crítica literária em continuar a problematizar essas duas formas de apreensão problematizadora do real, a literatura e a história. Desse modo, essa antologia de ensaios contribui para os estudos literários à medida que propõe leituras de textos contemporâneos que, por sua vez, voltam-se ao passado.

Além disso, os artigos deste volume trazem à tona romances, crônicas, poemas, peças de teatro, músicas e filmes que desnudam a violência e o autoritarismo desses dois momentos obscuros de extrema barbárie da história do Brasil e de Portugal, a ditadura militar brasileira e o salazarismo, respectivamente. Isto, no atual contexto mundial de ressurgimento de ideais conservadores, legitimadores de regimes autoritários mais ou menos disfarçados de democracia que, com efeito, nos aproximam de novos momentos sombrios.

\section{Referências}

BENJAMIN, Walter. Magia e técnica, arte e política. Trad. de Sérgio Paulo Rouanet. 8. ed. São Paulo: Brasiliense, 2012. 
RICOEUR, Paul. Tempo e Narrativa III. Trad. de Roberto Leal Ferreira. Campinas: Papirus, 1997.

RODRIGUES, Inara de Oliveira; NIEDERAUER, Silvia (org.). Brasil e Portugal: a ditadura entre luzes e sombras - leituras literárias. Frederico Westphalen: Universidade Regional Integrada do Alto Uruguai e das Missões, 2015. https://doi. org/10.5327/z201600040008rbm

Recebido em: 24/7/2018.

Aprovado em: 15/4/2019.

\section{Ernani Hermes}

Universidade Regional Integrada do Alto Uruguai e das Missões (URI)

Orcid: http://orcid.org/oooo-0002-0029-2627

E-mail: ernani.hermes@gmail.com

Endereço de correspondência: AV. $1^{\circ}$ DE MAIO, N ${ }^{\circ}$ 1410. Centro. CERRO GRANDE - RS. CEP: 98340-000 